\title{
"The low fee entry strategy and first mover advantage in the ETF market"
}

\begin{tabular}{|c|c|}
\hline AUTHORS & $\begin{array}{l}\text { Mina Glambosky (D https://orcid.org/0000-0001-6112-3619 } \\
\text { Kimberly Gleason } \\
\text { Chun Lee } \\
\text { Maryna Murdock }\end{array}$ \\
\hline ARTICLE INFO & $\begin{array}{l}\text { Mina Glambosky, Kimberly Gleason, Chun Lee and Maryna Murdock (2019). The } \\
\text { low fee entry strategy and first mover advantage in the ETF market. Investment } \\
\text { Management and Financial Innovations, 16(2), 281-294. } \\
\text { doi:10.21511/imfi.16(2).2019.24 }\end{array}$ \\
\hline DOI & http://dx.doi.org/10.21511/imfi.16(2).2019.24 \\
\hline RELEASED ON & Thursday, 20 June 2019 \\
\hline RECEIVED ON & Thursday, 21 March 2019 \\
\hline ACCEPTED ON & Tuesday, 11 June 2019 \\
\hline LICENSE & $\begin{array}{l}(c) E Y \quad E \\
\text { This work is licensed under a Creative Commons Attribution } 4.0 \text { International } \\
\text { License }\end{array}$ \\
\hline JOURNAL & "Investment Management and Financial Innovations" \\
\hline ISSN PRINT & $1810-4967$ \\
\hline ISSN ONLINE & $1812-9358$ \\
\hline PUBLISHER & LLC "Consulting Publishing Company "Business Perspectives" \\
\hline FOUNDER & LLC "Consulting Publishing Company "Business Perspectives" \\
\hline
\end{tabular}

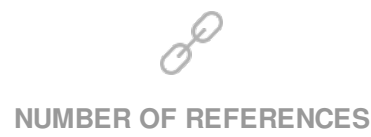

24
NUMBER OF FIGURES

0
=:-

NUMBER OF TABLES

6

(C) The author(s) 2023. This publication is an open access article. 


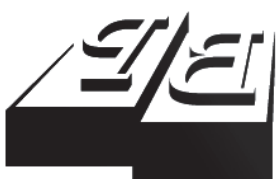

BUSINESS PERSPECTIVES

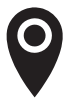

LLC "CPC "Business Perspectives" Hryhorii Skovoroda lane, 10, Sumy, 40022, Ukraine

www.businessperspectives.org

Received on: $21^{\text {st }}$ of March, 2019 Accepted on: $11^{\text {th }}$ of June, 2019

(C) Mina Glambosky, Kimberly Gleason, Chun Lee, Maryna Murdock, 2019

Mina Glambosky, Ph.D., Assistant Professor of Finance, Brooklyn College - CUNY, USA.

Kimberly Gleason, Ph.D., Associate Professor, University of Sharjah, UAE.

Chun Lee, Ph.D., Professor of Finance, Loyola Marymount University, USA.

Maryna Murdock, Ph.D., Associate Professor, University of North Georgia, USA.

\section{(ㄷ)(ㄱ)}

This is an Open Access article, distributed under the terms of the Creative Commons Attribution 4.0 International license, which permits unrestricted re-use, distribution, and reproduction in any medium, provided the original work is properly cited.
Mina Glambosky (USA), Kimberly Gleason (UAE),

Chun Lee (USA), Maryna Murdock (USA)

\section{THE LOW FEE ENTRY STRATEGY AND FIRST MOVER ADVANTAGE IN THE ETF MARKET}

\begin{abstract}
Academic literature struggles to explain investors' attitude towards fees and expenses charged by mutual funds. In general, investors have been found to exhibit a puzzling lack of interest in this non-trivial component of their total return, raising questions of rationality of real-world investor behavior. An emergence of exchange-traded funds (ETFs), their rapid proliferation in the past decades and distinct features, such as more simple expense structure, present a valuable opportunity to contribute to the debate surrounding the pricing of funds. To better understand the expense policy/fund flows dynamics, the authors first test a conjecture that later entrants in the ETF markets face a disadvantage in competition for fund flows. Then, they test whether competitive pressure can be successfully overcome by lowering expenses charged to ETF investors. The results suggest that, though it is not necessary to be a first entrant in a fund category to enjoy competitive advantage, an earlier market entry is beneficial for attracting fund flows. It is also found that later entrants' to the ETF market successfully use the strategy of reducing their expense ratios. Firms with lower net expense ratios obtain greater investment, as evidenced by greater capitalization and market share, supporting our intuition that investors may acknowledge the merits of low-cost ETFs.
\end{abstract}

Keywords

JEL Classification exchange-traded funds, asset management, pricing strategy, competition

\section{INTRODUCTION}

Exchange-traded funds (ETFs) and mutual funds enable individual investors to cheaply and simply diversify assets, as well as select the manner of diversification. By investing in mutual funds and ETFs, investors can access a broad market, or limit the degree of diversification to a certain asset type or a preferred industry segment. Both ETFs and mutual funds allow investors to reduce the idiosyncratic risk inherent in investing in only a handful of equities. Since their shares freely trade on exchanges and can be shorted, some view ETFs as a more attractive proposition than mutual funds. In contrast to index funds, ETFs can be traded intraday and have no investment minimums. In addition, ETFs provide more flexibility for investors who prefer a particular underlying asset type, affording more custom-made indexing opportunities. In certain cases, ETFs can also provide investors with tax advantages (Gastineau, 2001). One of the ETFs' most attractive features is its low fees, which are lower than those of even the least expensive mutual funds.

The relatively new ETFs market has experienced a substantial amount of market entry since ETFs originated in 1989 on the Toronto Stock Exchange (and in the US in 1993). The number of ETFs has grown to over 1,000 index funds since the origination of the ETFs market in 2012, the final year of our analysis. This growth means that new funds that enter the 
market face competition with the existing funds. Competition strategies have become increasingly complex after a relaxation of restrictions in 2008 allowed ETFs to deviate from the original index structure. New market entrants must find ways to attract investors, including lowering costs, as illustrated in Salisbury (2012): "Although BlackRock has proved reluctant to cut fees, some experts say not doing so means risking its No. 1 title. Today, the average iShares stock fund levies fees totaling \$46 per \$10,000 invested, compared with $\$ 17$ for Vanguard, according to S\&P Capital IQ. "Cutting prices is the only thing you can do", says industry consultant James Pacetti. "How else can you compete?" One option, some experts say, is for the company to innovate once again. But with almost 1,500 ETFs now available, analysts say coming up with something that still wows investors will be no easy task".

Anecdotal evidence suggests that later ETFs market entrants experience barriers, which they have attempted to overcome by waiving or lowering their fees. Newer ETFs start with smaller net asset values (NAVs) than existing ETFs. All else being equal, higher NAVs translate into a higher trading volume. This liquidity difference should translate into trading cost differences for ETF investors, introducing an additional factor in newer ETFs' uphill climb toward higher NAVs. This may provide a further incentive for the new entrants to reduce their expense ratios.

Although mutual funds trace their history to the early 1920s, until the late 1980s, academic literature generally did not address how funds determined fees, or their effect on investment decisions. Since 1980s, many studies have examined mutual fund fees' determinants, the effect of competition on pricing, whether pricing affects mutual funds' demand, and the factors that explain price sensitivity variation for various mutual fund products. To the best of our knowledge, however, there have been few, if any, attempts to directly investigate and explain these issues as they relate to exchange-traded funds. This paper attempts to fill this gap.

To this end, we pursue two lines of inquiry. First, we attempt to contribute to understanding of investors' attitudes towards pricing of financial products. Second, we attempt to identify factors that contribute to competition for fund flows. These two goals are related to the extent that, theoretically, investors are expected to consider various fees and expenses, in addition to performance and returns, when deciding where to direct their investment funds. However, it has been suggested in the mutual funds literature that mutual funds' investors' motivations are more complex as they make these decisions, according to Navone (2012), "....along multiple dimensions". We believe that the ETFs vehicle streamlines these decision drivers due to the simpler fee structure. In addition, the ETFs market offers a cleaner test of our research question due to a continuous proliferation of new funds and the relative ease of creation and redemption of shares. The unique features of ETFs allow for isolation and removal of some market frictions, which may cause the distortions in the mutual funds investors decision-making process. Thus, a separate investigation of the relationship between ETFs expenses and fund flows is worthwhile and relevant.

Our research strategy is to compare early versus late ETFs market entrants' ability to attract investment funds, conditioned on each product's cost. We investigate later entrants' effective price-cutting strategies to provide further evidence regarding the price sensitivity of investment fund flows to exchange-traded funds.

\section{RELEVANT LITERATURE AND THEORETICAL FRAMEWORK}

Since prior research on ETF expense ratio determinants is scarce and given the many similarities between mutual funds and ETFs, we start with re- viewing the literature investigating mutual funds' cost dynamics.

\subsection{Investor rationality assumption}

Most influential asset pricing theories, in their pure form, rely on an assumption of investor rationality. Economically rational investors can be 
expected to net their investment returns for two purposes: determining the investment's total return and comparing the net return with that of other available investments. Under these conditions, and if the net return remains marginally higher after accounting for all costs, funds that recently performed well should be able to charge higher fees ${ }^{1}$. It would also result in higher net fund flows to instruments that charge lower fees, all else being equal.

At the same time, empirical tests of classic price theories, such as the portfolio theory, reveal that real-world investors often behave in ways incompatible with the rationality assumption (Odean, 1998, 1999; Barber \& Odean, 2001; Jegadeesh \& Titman, 2003). In fact, modern modifications of price theories incorporate investors' deviations from optimal choices into the models (De Long et al., 1990). Though these early works focus on individual equity investments, the same principles apply to investments in portfolios of assets, specifically in various types of mutual funds. We review the literature related to investors' choices of mutual funds in the next subsection.

\subsection{Mutual funds' fees and fund flows}

A body of work exploring the relationship between fund flows and fund fees uncover a puzzling, but persistent pattern: investors seem to ignore fees charged by mutual funds and focus either on performance or on non-portfolio considerations. Hortacsu and Syverson (2004) point out that index funds proliferated in the 1990s at both the highest and lowest fee levels, because investors prioritize non-portfolio considerations. Furthermore, empirical studies suggest that investors neglect to subtract management or other fees from cash flows created by changes in funds' net asset values (Capon et al., 1996; Wilcox, 2003; Choi et al., 2010). Still, other empirical studies find a negative correlation between funds' performance and their expense ratios (Gruber, 1996; Carhart, 1997; Christoffersen \& Musto, 2002; Gil-Bazo \& RuizVerdu, 2009).
Christoffersen and Musto (2002), Gil-Bazo and RuizVerdu (2009) suggest that this negative relationship generally does not contradict the rationality assumption. They conclude that investors who are performance-sensitive also appear to be price-sensitive. Well-managed funds attract investors who are sensitive to "net" performance, whereas poorly-managed funds attract investors who are insensitive to net or gross performance.

However, several other studies imply that investors do not consider expense ratios simply as a negative component of net performance. Surveys conducted by Capon et al. (1996), Wilcox (2003) and Choi et al. (2010) reveal that, at least for some investors, price does not carry the same relevance as performance. Investors generally appear to be more performancethan price-sensitive. A study by Navone (2012) indicates that the negative relationship between performance and price is more pronounced for lesser-performing funds, whereas investors in better-performing funds do not appear to be cost-sensitive. The author also documents fund managers' opportunistic behavior, including adjusting expense ratios to changes in investors' price sensitivities. Beyond opportunistic pricing, the puzzling differential in investors' attitudes towards performance and costs risks exploitation by both mutual funds' and ETFs' managers aiming to attract and manage funds flows.

Ivkovic and Weisbenner (2009) suggest that individual investors may interpret high expense ratios and loads as a signal of high-quality fund management and services provided. They may then encourage the inflow of funds. High fees may also be used to pay for advertising expenses, which could result in higher inflows of new money. On the other hand, higher fees may cause higher redemption rates, as "old money" leaves more costly funds for less costly ones. This results in the almost negligible overall effect of expense ratios on net fund flows, consistent with Navone's (2012) result for better-performing funds. Jain and Wu (2000) document a positive investor response to mutual fund advertisement. A positive relationship between the inflows and management fees is also consistent with an earlier work by Barber, Odean, and Zheng (2005) who show that this positive relationship is confined to $12 \mathrm{~B}-1$ advertising fees.

$1 \quad$ Here "fees" refer to all costs incurred by investors. Since ETFs do not charge upfront fees (front-end loads) or redemption fees (backend loads), the annual operating fee (the expense ratio) is the only relevant charge. However, the fee includes both service charges and dividends received but not yet paid out. 


\subsection{ETF fees and fund flows}

Pertaining specifically to ETFs fees, Elton (2002) finds an insignificant relationship between SPDR fees and performance. Kostovetsky (2003) and Agapova (2011) find that ETFs offer a more investor-friendly fee structure than conventional index mutual funds. Agapova (2011) finds that ETFs' cash flows negatively relate to the expense ratio magnitude, while conventional index mutual funds' flows positively relate to expense ratios. Since Agapova (2011) aims toward substitutability of the two product families, she does not further explore this conundrum.

We rely on these findings to shed light on the relationship between ETFs' cash flows and their expense ratios. We attempt to investigate whether the cost-cutting trend helps new entrants in the ETFs market overcome any disadvantages associated with later market entry.

\section{HYPOTHESES}

Investor's perception of quality influences their tolerance of management fees. For example, studies have shown that investors associate higher expense ratios with well-managed funds, and the relatively high fee is likely used to promote the ETFs to investors (Jain \& Wu, 2000; Barber et al., 2005; Navone, 2012). If investors interpret an ETF's relative age as a sign of quality, they may be willing to accept higher expense ratios. If that is true, then fund flows will positively correlate with ETFs entry chronological order, as well as expense ratios.

Alternatively, investors may exhibit economically rational behavior in their preference for low versus high costs. While fund flows would still favor older funds, all else being equal, more recent entries may entice investors by charging lower fees. In this case, net asset values (NAVs) at any time should positively correlate with the proxies for early entry, and negatively correlate with expense ratios.

\section{DATA AND METHODOLOGY}

We collect the lists of ETFs at the end of each year from 1993 to 2012 from Morningstar Direct
Database. The data are used to determine the number of ETFs issued each year since the market introduction of this investment option. These data also allow us to identify the first entrants in each category (family) of ETFs products, as well as the chronological order of later entrants. We process this information to create a dummy variable FirstEntry to indicate whether the fund is the first entrant in its category. We also collect data for the net asset values and net expense ratios from the Morningstar Database on four randomly selected dates between January and August 2012: January 27, May 23, June 24, and August 6.

We conduct a series of univariate tests and a regression analysis to investigate if the low fee strategy allows a later ETF market to overcome the advantage enjoyed by first entrants and other incumbents. We use the following regression equation to estimate the direction and magnitude of ETF costs' effect on their fund flows:

$$
\begin{aligned}
& \ln \left(\text { Net asset } \text { value }_{i}\right)=+\alpha+\beta_{1} \times \\
& \times \text { First entrant }_{i} \text { or Largest fund } \text { Lat }_{i}+ \\
& +\gamma_{1} \cdot \text { Net expense ratio }_{i}+ \\
& +\gamma_{2} \cdot \text { Age of fund } \text { fu }_{i}+ \\
& +\gamma_{3} \cdot \text { NAVFundFamily }_{i}+\varepsilon_{i}
\end{aligned}
$$

where $\ln \left(\right.$ Net asset value $\left._{i}\right)$ is the natural logarithm of total net asset value of the ETF on one of the four randomly selected dates in 2012,

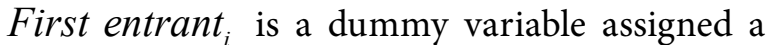
value of " 1 " if the ETF is the first ETF in its category and " 0 " otherwise, Net expense ratio ${ }_{i}$ is the net expense ratio of ETF, , Age of fund fis $_{i}$ the natural log of the length of time since the inception of the fund, NAVFundFamily ${ }_{i}$ is the total NAV of all other funds in the same family group.

The FirstEntry dummy variable can take on a value of either one or zero and indicates whether the ETF is the first ETF in a category. The advantage of the first entrant ETF may be enhanced by their entrenchment. The entrenchment effect reflects the advantage gained by the first entrants over later entrants, stemming from brand recognition. Since brand recognition depends on the length of time since a fund's inception, we include fund age as the control variable. An alternative approach uses the size of the fund 
(LargestFund) as a proxy for reputational capital. A positive and statistically significant $\beta_{1}$ would indicate that reputational capital using a first entrant strategy or visibility in the form of being the largest fund in a category attracts subsequent investor funds.

A negative and statistically significant $\gamma_{1}$ would suggest that a low cost strategy may incrementally influence the ability of the ETF to attract investor's funds. Presenting a lower cost alternative may allow the newer ETFs to attract new investment. These funds would continue to enter the existing ETFs if other new entrants do not use the low cost strategy, resulting in a higher future net asset value for existing ETFs. A negative and statistically significant coefficient on the net expense ratio variable would indicate that a low cost strategy is, incrementally, successful regardless of whether a fund was a first entrant or not. A positive and statistically significant coefficient of the age variable would suggest that older and more established funds that may have greater reputational advantages yield greater investor interest. Another important control variable is the size of the ETF provider in other areas (i.e., the NAV of the other funds in the same family group), which could be a proxy for reputational advantage of the fund. A positive and statistically significant $\gamma_{3}$ coefficient would indicate that regardless of whether a fund is a first entrant or not, larger and more "visible" ETF providers attract greater investment.

We further demonstrate the relationship between expense ratio and asset size by investigating how the market landscape changes over time after the entrance of the low cost ETF. We compare the changes in market capitalization for the first mover one and two years after the entrance of the Vanguard ETF (the later entrant), for the Vanguard ETF itself and for other funds in the same category. We focus on Vanguard, because it pioneered and continues to champion low costs in mutual funds and exchange-traded funds. To calculate market capitalization, we collect ETF prices and the number of outstanding shares from the University of Chicago's Center for Research in Security Prices (CRSP) database. We use price and number of outstanding shares to calculate each ETF's market capitalization on the one- and two-year anniversaries of Vanguard ETF's inception.

The above empirical approach implicitly assumes that the market remains flat over the study data time period. In additional tests, we use the market adjusted market cap, where the SPY exchange-traded fund represents the market. When the overall market trends up or down in terms of investor sentiment, we control for the effect of the aggregate appetite for equity and fund flows to the ETF. We also use a market share proxy for additional robustness tests.

\section{RESULTS}

\subsection{Basic statistics}

Table 1 reports the number of ETFs domiciled in the United States each year from 1993 to 2012, based on the data collected from the Investment Company Institute Factbook (2016). The first two ETFs introduced in the US market were the SPDR S\&P 500 (ticker SPY) and SPDR S\&P MidCap 400 (ticker MDY), with inception dates on January 22, 1993 and May 4, 1995, respectively. The State Street Corporation sponsored these first ETFs. The second firm, iShares, entered the market in 1996, with 17 ETFs on March 12. Each of the 17 iShares ETFs benchmarked the MSCI index for one of seventeen countries, including the three largest ETFs for Japan, Canada, and Australia. The table also documents the ETF market's impressive growth, which can be plausibly explained by ETFs' attractive features, such as their liquidity and low fees, as discussed above.

Table 1. Number of US exchange-traded funds by year

Sources: Investment Company Institute Factbook $(2016)^{2}$

\begin{tabular}{ccc}
\hline Year & Number of ETFs \\
\hline 1993 & 1 \\
1994 & 1 \\
1995 & 2 \\
1996 & 19 \\
1997 & 19 \\
1998 & 29 \\
1999 & 80 \\
2000 & 102 \\
2001 & 113 \\
2002 & 119 \\
\hline 2003 &
\end{tabular}

2 ICI lists the number of funds that are registered under the Investment Company Act of 1940 and excludes ETFs that primarily invest in other ETFs. This and other restrictions may result in a total number of US ETFs in any particular year to differ slightly from the number of observations in the regression analysis. We used the ICI data here, because it is presented in a convenient format for illustrating the rise in the importance of exchange-traded funds over time, while regression analysis uses data for year 2012 only. 
Table 1 (cont). Number of US exchange-traded funds by year

\begin{tabular}{c:c}
\hline Year & Number of ETFs \\
\hline 2004 & 152 \\
2005 & 359 \\
2006 & 629 \\
2007 & 728 \\
2008 & 997 \\
2009 & 923 \\
2010 & 1134 \\
2011 & 1194 \\
\hdashline & \\
\hdashline & \\
\hdashline
\end{tabular}

Table 2 shows the NAV, as well as the number of funds as of August 6, 2012 for the 47 US ETF spon- sors. iShares, the second firm to issue ETFs, ranks number one in terms of total NAVs $(40.93 \%$ of the total value of all ETFs in circulation), as well as the number of funds. iShares is followed by State Street, the issuer of first ETFs (24.44\% of the ETF market), as well as by Vanguard, ranked third, capturing $17.83 \%$ of the market. Notably, SPY is the oldest and largest ETF, with a NAV of over 106 billion. Compared with iShares and State Street, Vanguard's ETFs have the highest average, minimum, median, and maximum NAVs, if SPY is excluded.

Table 2. Statistics of ETF providers by net asset value and the number of ETFs as of August 6, 2012

\begin{tabular}{|c|c|c|c|c|c|c|c|c|c|}
\hline \multirow[b]{2}{*}{ Name } & \multicolumn{7}{|c|}{ Net asset value in USD thousands } & \multicolumn{2}{|c|}{ Number of funds } \\
\hline & NAV & $\begin{array}{c}\text { Ranking } \\
\text { among all } \\
\text { companies }\end{array}$ & $\begin{array}{c}\% \text { of all } \\
\text { companies }\end{array}$ & Minimum & Average & Median & Maximum & No. & $\begin{array}{c}\text { Ranking } \\
\text { among all } \\
\text { companies }\end{array}$ \\
\hline iShares & $497,755,000$ & 1 & 40.93 & 1,141 & $1,803,460$ & 213,964 & $35,095,000$ & 276 & 1 \\
\hline State Street & $297,217,000$ & 2 & 24.44 & 3,017 & $2,584,500$ & 172,697 & $106,220,000$ & 115 & 4 \\
\hline Vanguard & $216,879,000$ & 3 & 17.83 & 12,050 & $3,388,740$ & 906,689 & $53,126,000$ & 64 & 8 \\
\hline Powershares & $57,773,200$ & 4 & 4.75 & 1,447 & 458,517 & 48,589 & $33,584,000$ & 126 & 3 \\
\hline Van Eck & $24,214,500$ & 5 & 1.99 & 2,616 & 484,289 & 44,613 & $7,949,280$ & 50 & 11 \\
\hline Proshares & $22,078,800$ & 6 & 1.82 & 1,445 & 159,991 & 18,221 & $3,040,320$ & 138 & 2 \\
\hline WisdomTree & $15,637,300$ & 7 & 1.29 & 4,242 & 325,777 & 103,520 & $3,979,710$ & 48 & 12 \\
\hline Deutsche Bank & $12,799,900$ & 8 & 1.05 & 1,388 & 232,724 & 19,991 & $6,114,070$ & 55 & 10 \\
\hline Guggenheim & $11,268,400$ & 9 & 0.93 & 3,017 & 144,466 & 57,784 & $2,733,460$ & 78 & 6 \\
\hline First Trust & $7,548,554$ & 10 & 0.62 & 1,141 & 107,836 & 36,875 & 665,030 & 70 & 7 \\
\hline Schwab & $7,059,350$ & 11 & 0.58 & 156,388 & 470,623 & 435,966 & $1,040,230$ & 15 & 19 \\
\hline PIMCO & $7,053,384$ & 12 & 0.58 & 2,858 & 371,230 & 111,620 & $2,401,670$ & 19 & 17 \\
\hline Barclays & $6,610,786$ & 13 & 0.54 & 638 & 81,614 & 6,182 & $2,067,770$ & 81 & 5 \\
\hline Direxion & $6,015,086$ & 14 & 0.49 & 1,092 & 107,412 & 19,031 & $1,183,340$ & 56 & 9 \\
\hline JPMorgan & $5,104,347$ & 15 & 0.42 & 3,445 & $1,276,090$ & 7,216 & $5,086,470$ & 4 & 34 \\
\hline ALPS & $4,061,704$ & 16 & 0.33 & 18,494 & 812,340 & 74,238 & $3,823,070$ & 5 & 31 \\
\hline ETFS & $3,684,770$ & 17 & 0.3 & 34,367 & 526,395 & 459,374 & $1,782,810$ & 7 & 25 \\
\hline $\begin{array}{l}\text { United States } \\
\text { Commodity Funds }\end{array}$ & $3,061,937$ & 18 & 0.25 & 2,386 & 255,161 & 48,246 & $1,174,220$ & 12 & 22 \\
\hline UBS & $1,281,508$ & 19 & 0.11 & 2,632 & 27,266 & 11,746 & 320,524 & 47 & 13 \\
\hline Global X Management & $1,202,186$ & 20 & 0.1 & 1,346 & 34,348 & 8,977 & 273,085 & 35 & 14 \\
\hline Swedish Export Credit & $1,154,514$ & 21 & 0.09 & 1,126 & 144,314 & 33,981 & 592,256 & 8 & 24 \\
\hline Northern Trust & $1,140,480$ & 22 & 0.09 & 105,600 & 285,120 & 296,041 & 442,797 & 4 & 35 \\
\hline Credit Suisse & $1,049,997$ & 23 & 0.09 & 488 & 37,499 & 7,761 & 268,758 & 28 & 15 \\
\hline $\begin{array}{l}\text { Emerging Global } \\
\text { Advisors }\end{array}$ & 707,339 & 24 & 0.06 & 1,631 & 37,228 & 4,043 & 416,314 & 19 & 18 \\
\hline Advisorshares & 657,621 & 25 & 0.05 & 2,497 & 43,841 & 14,024 & 347,153 & 15 & 20 \\
\hline GreenHaven|GCC & 505,012 & 26 & 0.04 & 505,012 & 505,012 & 505,012 & 505,012 & 1 & 40 \\
\hline IndexiQ & 488,492 & 27 & 0.04 & 1,588 & 40,707 & 26,572 & 208,910 & 12 & 23 \\
\hline VTL Associates & 429,090 & 28 & 0.04 & 7,885 & 71,515 & 70,568 & 153,676 & 6 & 29 \\
\hline Russell & 316,467 & 29 & 0.03 & 2,484 & 12,171 & 5,156 & 68,302 & 26 & 16 \\
\hline Goldman Sachs & 259,769 & 30 & 0.02 & 8,595 & 129,884 & 129,884 & 251,174 & 2 & 36 \\
\hline Fidelity & 187,232 & 31 & 0.02 & 187,232 & 187,232 & 187,232 & 187,232 & 1 & 41 \\
\hline Precidian Investments & 182,128 & 32 & 0.01 & 182,128 & 182,128 & 182,128 & 182,128 & 1 & 42 \\
\hline RBS & 166,949 & 33 & 0.01 & 3,792 & 23,849 & 10,592 & 76,887 & 7 & 26 \\
\hline Morgan Stanley & 164,366 & 34 & 0.01 & 810 & 27,394 & 14,873 & 79,560 & 6 & 30 \\
\hline Teucrium & 130,495 & 35 & 0.01 & 1,490 & 18,642 & 3,535 & 104,570 & 7 & 27 \\
\hline Focusshares & 94,193 & 36 & 0.01 & 2,128 & 6,279 & 5,912 & 19,928 & 15 & 21 \\
\hline FQF & 60,864 & 37 & 0.01 & 3,503 & 8,694 & 5,228 & 29,853 & 7 & 28 \\
\hline $\begin{array}{l}\text { Exchange Traded } \\
\text { Concepts }\end{array}$ & 50,742 & 38 & 0 & 2,202 & 25,371 & 25,371 & 48,540 & 2 & 37 \\
\hline Columbia & 25,194 & 39 & 0 & 1,500 & 5,038 & 5,332 & 8,178 & 5 & 32 \\
\hline Pax World & 18,957 & 40 & 0 & 8,847 & 9,478 & 9,478 & 10,109 & 2 & 38 \\
\hline $\begin{array}{l}\text { Stream Exchange } \\
\text { Traded Trust }\end{array}$ & 16,721 & 41 & 0 & 16,721 & 16,721 & 16,721 & 16,721 & 1 & 43 \\
\hline Factor Shares & 14,905 & 42 & 0 & 1,083 & 2,981 & 2,012 & 8,321 & 5 & 33 \\
\hline Arrowshares & 11,309 & 43 & 0 & 11,309 & 11,309 & 11,309 & 11,309 & 1 & 44 \\
\hline Huntington Funds & 10,288 & 44 & 0 & 3,858 & 5,144 & 5,144 & 6,430 & 2 & 39 \\
\hline Citigroup & 3,590 & 45 & 0 & 3,590 & 3,590 & 3,590 & 3,590 & 1 & 45 \\
\hline AlphaClone & 2,792 & 46 & 0 & 2,792 & 2,792 & 2,792 & 2,792 & 1 & 46 \\
\hline Apex Capital & 117 & 47 & 0 & 117 & 117 & 117 & 117 & 1 & 47 \\
\hline Total & $1,216,156,355$ & - & 100 & - & - & - & - & 1487 & - \\
\hline
\end{tabular}


Table 3. Comparison of Vanguard ETFs with first movers

\begin{tabular}{|c|c|c|c|c|c|}
\hline \multirow{2}{*}{ Category } & \multicolumn{2}{|c|}{ Vanguard ETFs } & \multicolumn{3}{|c|}{ Difference between vanguard and first mover } \\
\hline & Inception & Expense ratio & Inception, years & Fee & Fee, $\%$ \\
\hline Communications & $09 / 23 / 04$ & 0.19 & 4.34 & -0.28 & -60 \\
\hline Consumer Cyclical & $01 / 26 / 04$ & 0.19 & 5.12 & 0.00 & 0 \\
\hline Consumer Defensive & $01 / 26 / 04$ & 0.19 & 5.12 & 0.00 & 0 \\
\hline Diversified Emerging Mkts & $03 / 04 / 05$ & 0.20 & 2.31 & -0.10 & -33 \\
\hline Diversified Pacific/Asia & $03 / 04 / 05$ & 0.14 & 2.31 & -0.16 & -53 \\
\hline Equity Energy & $09 / 23 / 04$ & 0.19 & 5.78 & 0.00 & 0 \\
\hline Europe Stock & $03 / 04 / 05$ & 0.14 & 8.98 & -0.37 & -73 \\
\hline Financial & $01 / 26 / 04$ & 0.19 & 5.12 & 0.00 & 0 \\
\hline Foreign Large Blend & $03 / 02 / 07$ & 0.18 & 5.55 & -0.16 & -47 \\
\hline Foreign Small/Mid Blend & $04 / 02 / 09$ & 0.28 & 2.80 & -0.30 & -52 \\
\hline Global Real Estate & $11 / 01 / 10$ & 0.35 & 3.88 & -0.26 & -43 \\
\hline Health & $01 / 26 / 04$ & 0.19 & 5.12 & 0.00 & 0 \\
\hline Industrials & $09 / 23 / 04$ & 0.19 & 5.78 & 0.00 & 0 \\
\hline Intermediate Government & $11 / 19 / 09$ & 0.14 & 2.87 & -0.01 & -7 \\
\hline Intermediate-Term Bond & $04 / 03 / 07$ & 0.10 & 3.53 & -0.10 & -50 \\
\hline Large Blend & $05 / 24 / 01$ & 0.05 & 8.34 & -0.04 & -44 \\
\hline Large Growth & $01 / 26 / 04$ & 0.10 & 4.88 & -0.10 & -50 \\
\hline Large Value & $01 / 26 / 04$ & 0.10 & 6.04 & -0.07 & -32 \\
\hline Long Government & $12 / 06 / 07$ & 0.13 & 5.38 & -0.02 & -13 \\
\hline Long-Term Bond & $04 / 03 / 07$ & 0.11 & 4.70 & -0.04 & -27 \\
\hline Mid-Cap Blend & $12 / 27 / 01$ & 0.10 & 6.65 & -0.15 & -60 \\
\hline Mid-Cap Growth & $08 / 17 / 06$ & 0.10 & 6.07 & -0.15 & -32 \\
\hline Mid-Cap Value & 08/17/06 & 0.1 & 6.07 & -0.15 & -60 \\
\hline Natural Res & $01 / 26 / 04$ & 0.19 & 5.12 & 0.00 & 0 \\
\hline Real Estate & $09 / 23 / 04$ & 0.1 & 4.28 & -0.37 & -79 \\
\hline Short Government & $11 / 19 / 09$ & 0.14 & 7.33 & -0.01 & -7 \\
\hline Short-Term Bond & $04 / 03 / 07$ & 0.11 & 0.24 & -0.09 & -45 \\
\hline Small Blend & $01 / 26 / 04$ & 0.1 & 3.68 & -0.10 & -50 \\
\hline Small Growth & $01 / 26 / 04$ & 0.1 & 3.51 & -0.15 & -60 \\
\hline Small Value & $01 / 26 / 04$ & 0.1 & 3.51 & -0.15 & -60 \\
\hline Technology & $01 / 26 / 04$ & 0.19 & 5.12 & 0.00 & 0 \\
\hline Utilities & $01 / 26 / 04$ & 0.19 & 5.12 & 0.00 & 0 \\
\hline World Stock & $06 / 24 / 08$ & 0.22 & 7.75 & -0.30 & -58 \\
\hline Minimum & & & 0.24 & -0.37 & -79 \\
\hline Average & & & 4.77 & -0.11 & -33 \\
\hline Median & & & 5.12 & -0.10 & -43 \\
\hline Maximum & & & 8.98 & 0.00 & 0 \\
\hline
\end{tabular}

Table 3 compares Vanguard and the first entrants. With an average time since the inception of the first entrant to the inception of a similar Vanguard fund of 4.77 years and median of 5.12 years, Vanguard clearly trails its largest competitors in entering the ETF market. Vanguard's decision to adopt a low fee strategy may be due to their need to overcome a later entry to the ETF market ${ }^{3}$. The average and median difference in fees is -0.11 and -0.10 percentage points, with the average and median percent change of $-33 \%$ and $-43 \%$. This paper's main focus is this cost-reducing strategy's efficacy in competing for investors and the resulting capital flows.

\subsection{Results of the regression analysis of first entrant advantage in the ETF industry}

To formally examine the relationship between asset size and expense ratio, as well as the first entrant effect, we perform a regression analysis specified in Model (1) on the four randomly selected days in 2012. Table 4 displays the results for August 6, 2012. Results for the other three days, not reported in this paper but available by request, are qualitatively similar.

3 Alternatively, Vanguard may have made the decision to enter the ETF market due to their ability to manage low cost funds. We thank a reviewer for this suggestion. Investigating the causality of Vanguard's decision to enter the ETF markets is generally outside the scope of this study. The main purpose of this paper is to investigate whether the low fee strategy overcomes the disadvantage presented by the later entry into the market. 
Table 4. Regression of net asset value (NAV) on FirstEntry, net expense ratio, age of fund, total NAV of fund family*

\begin{tabular}{|c|c|c|c|c|c|c|}
\hline Morningstar categories & Intercept & FirstEntry & $\begin{array}{c}\text { Net expense } \\
\text { ratio }\end{array}$ & Age of fund & $\begin{array}{c}\text { Total NAV of } \\
\text { funds* }\end{array}$ & $\operatorname{Adj}-R^{2}$ \\
\hline \multicolumn{7}{|c|}{ a. Industry } \\
\hline \multirow{2}{*}{ Commod. agriculture } & -6.07 & -0.91 & $4.89^{b}$ & $3.23^{c}$ & 0.24 & \multirow{2}{*}{$58.75 \%$} \\
\hline & $(-0.58)$ & $(-0.45)$ & $(2.66)$ & $(3.41)$ & $(0.74)$ & \\
\hline \multirow{2}{*}{ Commod. broad basket } & 14.55 & 1.89 & 4.12 & 0.52 & -0.04 & \multirow{2}{*}{$6.26 \%$} \\
\hline & $(1.69)$ & $(0.73)$ & $(0.85)$ & $(0.92)$ & $(-0.10)$ & \\
\hline \multirow{2}{*}{ Commod. energy } & $19.33^{\mathrm{b}}$ & 0.95 & -0.07 & $0.94^{\mathrm{a}}$ & -0.25 & \multirow{2}{*}{$9.87 \%$} \\
\hline & $(2.53)$ & $(0.47)$ & $(-0.45)$ & $(1.93)$ & $(-0.67)$ & \\
\hline \multirow{2}{*}{ Commod. industrial metals } & 7.91 & 0.57 & 10.5 & $2.94^{\mathrm{a}}$ & -0.56 & \multirow{2}{*}{$68.38 \%$} \\
\hline & $(0.55)$ & $(0.28)$ & $(0.76)$ & $(2.45)$ & $(-0.83)$ & \\
\hline \multirow{2}{*}{ Commod. precious metals } & -6.41 & $2.28^{\mathrm{b}}$ & 1.06 & 0.45 & 0.93 & \\
\hline & $(-1.59)$ & $(2.26)$ & $(0.84)$ & $(0.81)$ & $(3.42)$ & $94.40 \%$ \\
\hline & $15.04^{c}$ & -1.50 & 0.27 & $0.60^{\mathrm{c}}$ & -0.03 & \\
\hline Communications & $(5.78)$ & $(-1.40)$ & $(0.21)$ & $(6.46)$ & $(-0.29)$ & $88.04 \%$ \\
\hline & $16.23^{c}$ & 0.73 & -3.02 & $0.43^{c}$ & 0.00 & \\
\hline Financial & $(4.39)$ & $(0.39)$ & $(-1.55)$ & $(3.98)$ & $(0.07)$ & $49.15 \%$ \\
\hline & $14.58^{\mathrm{c}}$ & -0.57 & -1.89 & $0.45^{c}$ & 0.09 & \\
\hline Health & $(4.64)$ & $(-0.42)$ & $(-1.23)$ & $(5.05)$ & $(0.76)$ & $70.16 \%$ \\
\hline & $10.11^{\mathrm{c}}$ & 0.51 & 1.15 & $0.44^{c}$ & $0.18^{a}$ & \\
\hline Industrials & $(4.42)$ & $(0.37)$ & $(1.01)$ & $(4.84)$ & $(1.95)$ & $67.70 \%$ \\
\hline & $25.76^{c}$ & -1.63 & $-5.12^{\mathrm{b}}$ & $0.40^{\mathrm{c}}$ & $-0.26^{a}$ & \\
\hline Natural resource & $(6.11)$ & $(-0.79)$ & $(-2.15)$ & $(3.04)$ & $(-1.83)$ & $4.01 \%$ \\
\hline & $19.29^{\circ}$ & 0.05 & -2.95 & $0.52^{c}$ & -0.08 & \\
\hline Real estate & $(4.40)$ & $(0.03)$ & $(-1.30)$ & $(3.02)$ & $(-0.41)$ & $51.65 \%$ \\
\hline & $21.10^{c}$ & 0.96 & $-3.18^{a}$ & $0.42^{c}$ & -0.15 & \\
\hline lechnology & $(5.60)$ & $(0.66)$ & $(-1.90)$ & $(4.43)$ & $(-1.03)$ & $62.83 \%$ \\
\hline & $15.51^{\mathrm{c}}$ & 0.04 & -2.11 & $0.48^{c}$ & 0.02 & \\
\hline Utilities & $(5.14)$ & $(0.03)$ & $(-1.51)$ & $(4.64)$ & $(0.23)$ & $82.15 \%$ \\
\hline & & b. Regional & jeographic & & & \\
\hline & 6.14 & -2.83 & -0.35 & $0.40^{c}$ & $0.41^{c}$ & \\
\hline China region & $(1.23)$ & $(-1.35)$ & $(-0.08)$ & $(3.11)$ & $(3.00)$ & $67.37 \%$ \\
\hline & $20.81^{\mathrm{b}}$ & $-4.18^{\mathrm{b}}$ & $-4.41^{b}$ & $0.58^{c}$ & -0.05 & \\
\hline Diversitied emerging Mkts & $(5.86)$ & $(-2.23)$ & $(-2.73)$ & $(3.95)$ & $(-0.42)$ & $8.10 \%$ \\
\hline & 13.72 & -2.27 & 1.18 & $1.68^{\mathrm{b}}$ & 0.05 & \\
\hline Emerging markets bond & $(1.34)$ & $(-0.82)$ & $(0.14)$ & $(2.82)$ & $(0.12)$ & $46.75 \%$ \\
\hline & $13.16^{\mathrm{b}}$ & -1.80 & -2.72 & 0.11 & 0.22 & \\
\hline Europe stock & $(2.45)$ & $(-1.01)$ & $(-1.01)$ & $(1.60)$ & $(1.08)$ & $25.40 \%$ \\
\hline & $14.42^{\mathrm{b}}$ & $4.72^{\mathrm{b}}$ & $-4.65^{c}$ & -0.08 & 0.28 & \\
\hline Foreign large blend & $(3.40)$ & $(2.48)$ & $(-3.44)$ & $(-0.49)$ & $(1.68)$ & $68.57 \%$ \\
\hline & $6.83^{\mathrm{b}}$ & $-4.48^{c}$ & -1.37 & $0.56^{c}$ & $0.41^{\mathrm{c}}$ & \\
\hline Foreign large value & $(2.69)$ & $(-3.58)$ & $(-0.80)$ & $(5.42)$ & $(4.55)$ & $9.50 \%$ \\
\hline & -4.39 & 1.70 & 26.52 & -1.66 & 0.65 & \\
\hline Global real estate & $(-0.13)$ & $(0.52)$ & $(0.70)$ & $(-0.86)$ & $(0.74)$ & $8.0 / \%$ \\
\hline & $33.92^{b}$ & 2.40 & -6.67 & 0.24 & -0.53 & \\
\hline Japan stock & $(3.98)$ & $(0.95)$ & $(-1.83)$ & $(1.04)$ & $(-1.78)$ & $75.35 \%$ \\
\hline & $15.97^{c}$ & $-4.37^{\mathrm{b}}$ & -2.94 & $0.52^{c}$ & 0.08 & \\
\hline Latin America stock & $(3.34)$ & $(-2.26)$ & $(-1.09)$ & $(4.11)$ & $(0.53)$ & $1.09 \%$ \\
\hline & $11.76^{\mathrm{b}}$ & -0.08 & -5.38 & 0.13 & $0.38^{c}$ & \\
\hline Pacıitic/Asıa ex-Japan stock & $(2.40)$ & $(-0.06)$ & $(-1.46)$ & $(1.71)$ & $(2.80)$ & $65.11 \%$ \\
\hline World hond & $16.56^{\mathrm{b}}$ & 0.58 & -0.25 & $0.97^{c}$ & -0.01 & $787 \%$ \\
\hline World bond & $(3.41)$ & $(0.84)$ & -0.12 & $(5.83)$ & $(-0.09)$ & $1.8 / \%$ \\
\hline & -1.53 & -1.75 & 2.25 & -0.18 & $0.83^{c}$ & \\
\hline World stock & $(-0.29)$ & $(-1.32)$ & $(0.81)$ & $(-1.16)$ & $(4.15)$ & $74.05 \%$ \\
\hline & & c. Marke & cap size & & & \\
\hline & $14.62^{c}$ & 0.47 & $-4.38^{c}$ & $0.34^{c}$ & 0.14 & \\
\hline Large blend & $(5.26)$ & $(0.24)$ & $(-4.15)$ & $(3.93)$ & $(1.27)$ & $62.65 \%$ \\
\hline & $13.68^{\mathrm{b}}$ & 2.82 & -2.34 & $0.28^{\mathrm{b}}$ & 0.17 & \\
\hline Large growth & $(2.54)$ & $(1.59)$ & $(-1.21)$ & $(2.84)$ & $(0.89)$ & $68.64 \%$ \\
\hline & $15.56^{\mathrm{b}}$ & 1.12 & -2.28 & $0.20^{\mathrm{a}}$ & 0.14 & \\
\hline Large value & $(2.90)$ & $(0.54)$ & $(-1.07)$ & $(1.90)$ & $(0.72)$ & $5.01 \%$ \\
\hline & $17.34^{c}$ & -1.27 & $-3.49^{b}$ & $0.46^{c}$ & 0.00 & $6204 \%$ \\
\hline Mid-Cap Blend & $(3.48)$ & $(-0.65)$ & $(-2.40)$ & $(3.49)$ & $(0.04)$ & $62.04 \%$ \\
\hline & 15.40 & 1.10 & -3.83 & 0.20 & 0.13 & $4467 \%$ \\
\hline Mid-cap growth & $(1.88)$ & $(0.66)$ & $(-1.42)$ & $(1.30)$ & $(0.46)$ & $44.6 / \%$ \\
\hline & $19.68^{\mathrm{a}}$ & -0.57 & -2.88 & $0.52^{\mathrm{b}}$ & -0.11 & \\
\hline Mid-cap value & $(2.22)$ & $(-0.28)$ & $(-0.80)$ & $(2.48)$ & $(-0.36)$ & $30.27 \%$ \\
\hline & 15.32 & 1.00 & -3.00 & $0.47^{c}$ & 0.07 & $6074 \%$ \\
\hline Small blend & $(3.64)$ & $(0.58)$ & $(-1.54)$ & $(3.38)$ & $(0.42)$ & $60.74 \%$ \\
\hline & $25.90^{\circ}$ & 1.99 & -5.70 & $0.34^{b}$ & -0.31 & \\
\hline Small growth & $(2.11)$ & $(1.45)$ & $(-1.60)$ & $(3.02)$ & $(-0.70)$ & $70.93 \%$ \\
\hline Smallyalue & $20.86^{a}$ & 1.70 & -3.53 & $0.36^{c}$ & -0.14 & \\
\hline Small value & $(2.69)$ & $(1.32)$ & $(-1.62)$ & $(3.57)$ & $(-0.50)$ & $71.28 \%$ \\
\hline
\end{tabular}


Table 4 (cont.). Regression of net asset value (NAV) on FirstEntry, net expense ratio, age of fund, total NAV of fund family*

\begin{tabular}{|c|c|c|c|c|c|c|}
\hline Morningstar categories & Intercept & FirstEntry & $\begin{array}{c}\text { Net expense } \\
\text { ratio }\end{array}$ & Age of fund & $\begin{array}{l}\text { Total NAV of } \\
\text { funds* }\end{array}$ & $\mathrm{Adj}-R^{2}$ \\
\hline \multicolumn{7}{|c|}{ d. Financial/strategy } \\
\hline \multirow{2}{*}{ Consumer cyclical } & $13.49^{b}$ & 0.08 & -1.45 & $0.40^{b}$ & 0.11 & \multirow{2}{*}{$55.50 \%$} \\
\hline & $(3.07)$ & $(0.04)$ & $(-0.73)$ & $(2.65)$ & $(0.62)$ & \\
\hline \multirow{2}{*}{ Consumer defense } & $16.98^{\mathrm{c}}$ & 0.24 & -0.85 & $0.49^{c}$ & -0.04 & \multirow{2}{*}{$63.85 \%$} \\
\hline & $(4.18)$ & $(0.13)$ & $(-0.42)$ & $(3.25)$ & $(-0.29)$ & \\
\hline \multirow{2}{*}{ Currency } & 4.77 & 0.80 & 3.59 & $0.67^{a}$ & $0.33^{a}$ & \multirow{2}{*}{$9.86 \%$} \\
\hline & $(0.95)$ & $(0.44)$ & $(1.65)$ & $(2.05)$ & $(1.72)$ & \\
\hline \multirow{2}{*}{ Equity energy } & $24.35^{c}$ & -0.03 & -2.62 & $0.48^{c}$ & $-0.28^{a}$ & \multirow{2}{*}{$26.42 \%$} \\
\hline & $(6.27)$ & $(-0.01)$ & $(-1.41)$ & $(3.25)$ & $(-1.96)$ & \\
\hline \multirow{2}{*}{ High yield bond } & 29.19 & 1.13 & -2.97 & $1.51^{\mathrm{b}}$ & -0.48 & \multirow{2}{*}{$81.44 \%$} \\
\hline & $(1.71)$ & $(0.70)$ & $(-0.71)$ & $(3.28)$ & $(-0.74)$ & \\
\hline \multirow{2}{*}{ Intermediate government } & $21.72^{\mathrm{c}}$ & 0.57 & $-21.20^{c}$ & $0.65^{c}$ & -0.01 & \multirow{2}{*}{$7.85 \%$} \\
\hline & $(4.55)$ & $(0.34)$ & $(-3.47)$ & $(3.40)$ & $(-0.09)$ & \\
\hline \multirow{2}{*}{ Long government } & $15.82^{\mathrm{b}}$ & -0.17 & -1.83 & $0.59^{\mathrm{b}}$ & 0.02 & \multirow{2}{*}{$78.70 \%$} \\
\hline & $(3.32)$ & $(-0.15)$ & $(-0.21)$ & $(3.48)$ & $(0.14)$ & \\
\hline \multirow{2}{*}{ Long/short equity } & 19.75 & -0.06 & -1.74 & 0.65 & -0.07 & \multirow{2}{*}{$54.52 \%$} \\
\hline & $(1.40)$ & $(-0.02)$ & $(-0.24)$ & $(1.33)$ & $(-0.17)$ & \\
\hline \multirow{2}{*}{ Trading-inverse commod. } & 4.34 & 0.86 & 12.26 & 1.72 & -0.20 & \multirow{2}{*}{$7.90 \%$} \\
\hline & $(0.35)$ & $(0.58)$ & $(1.59)$ & $(1.42)$ & $(-0.26)$ & \\
\hline \multirow{2}{*}{ Trading-inverse debt } & -0.38 & 1.20 & 0.42 & $1.57^{c}$ & 0.57 & \multirow{2}{*}{$71.99 \%$} \\
\hline & $(-0.01)$ & $(0.70)$ & $(0.09)$ & $(3.55)$ & $(0.43)$ & \\
\hline \multirow{2}{*}{ Trading-inverse equity } & 24.57 & $3.64^{a}$ & 1.11 & $0.48^{c}$ & -0.45 & \multirow{2}{*}{$12.80 \%$} \\
\hline & $(1.71)$ & $(1.94)$ & $(0.47)$ & $(2.74)$ & $(-0.71)$ & \\
\hline \multirow{2}{*}{ Trading } & 35.25 & $3.01^{\mathrm{a}}$ & 0.17 & $0.57^{c}$ & $-0.86^{c}$ & \multirow{2}{*}{$3.07 \%$} \\
\hline & $(4.55)$ & $(1.93)$ & $(0.04)$ & $(3.85)$ & $(-3.06)$ & \\
\hline
\end{tabular}

Notes: *Total NAV of fund family is the total net asset value of all other funds in the same family group; a: significant at $10 \%$; b: significant at $5 \%$; c: significant at $1 \%$.

To ensure that the number of observations is sufficient to render the regression analysis powerful, we exclude ETFs with fewer than ten individual funds in all categories. This elimination reduces the number of ETFs included in the analysis to 1,212 in 47 categories, down from the total of 1,487 ETFs in 64 categories. We perform the regression analysis separately for each fund category.

Analyzing the results of Model 1 across ETF categories reveals that first entrants in the market generally enjoy higher investment fund flows; most the 1 coefficients are positive, but only 4 out of 47 are positive and significant. This indicates that there is little evidence of a statistically significant first entrant advantage.

Analysis of the $\gamma_{1}$ coefficient allows us to make a judgment regarding the effectiveness of the later ETF entrants' cost-cutting strategy. The coefficient for the Expense Ratio is negative and significant in 7 cases. The remaining Expense Ratio coefficients are for the most part negative, but statistically insignificant. Only one $\gamma_{1}$ coefficient, for the Commodity/Agriculture ETF, is positive and statistically significant. On the other hand, the $\gamma_{2}$ (age) coefficient is positive and significantly related to NAV for 35 of the funds. These results indicate that while the evidence on the first entrant advantage is equivocal, age significantly and positively relates to fund flows ${ }^{4}$. The cost-cutting strategy likely helps the later entrants make headway in the ETF market, even after controlling for fund family size. These results are also consistent with Agapova (2011) who finds that fund flows negatively relate to ETF expenses. Finally, the $\gamma_{3}$ coefficient, which provides evidence regarding the relationship between the size of the ETF provider and NAV, is positive and significant for five funds, but negative and significant for four. Therefore, our results do not support the conjecture that reputational advantage, or ETF provider visibility impacts NAV. Taken together, we find evidence to suggest that both extent of establishment in the ETF market (i.e., age), and a low cost strategy offer benefits in increasing NAV, although a first entrant strategy does not.

Results for the other three days are similar and available upon request. We also perform a regression analysis estimated in Model 1, substituting the log of NAV with the total net asset value as the

4 In additional robustness tests, we run regressions without the first entrant variable, and results are similar. The main conclusion is still that age is the most important factor in increasing NAV. We thank an anonymous reviewer for suggesting these tests. 
dependent variable with similar results. Finally, additional robustness tests using largest fund as a proxy for reputational capital rather than first entrant are performed. We find that the results for largest fund are qualitatively similar to those presented for first entrant, with the interpretation being comparable 5 .

\subsection{Results of the analysis of capitalization after the entry of low-fee ETF}

The regression results reported in Table 4 suggest that the ETF market exhibits a strong age effect, which later entrants can possibly diminish or overcome with a low-fee strategy. We investigate this by testing how low fee provider Vanguard gained a foothold in the market despite being disadvantaged by reputation effects when related to the older providers. We perform this investigation by comparing Vanguard's change in market capitalization to that of a first entrant and other existing ETFs one and two years after the inception of Vanguard ETFs.

Vanguard sponsors ETFs in 33 out of a total 64 existing ETF categories. For categories in which Vanguard has more than one ETF, we select for comparison the oldest Vanguard ETF in that category. Table 5 describes the changes in market capitalization, adjusted for the overall movement of the market using the SPY as the market index for first entrants, largest funds (defined as the fund with the highest market capitalization in each category before the entry of the Vanguard low fee fund), and other funds versus the Vanguard ETF'

Our tests reveal that the largest fund enjoys an average increase of $64.73 \%$ and a median increase of $17.03 \%$ in market capitalization one year after the introduction of Vanguard ETFs. By comparison, the Vanguard ETFs achieve an average increase of $593.61 \%$ and a median increase of $182.11 \%$. Judging by the fact that Vanguard ETFs have a greater maximum increase of $4,139.78 \%$ and minimum of
$-72.83 \%$, compared to a maximum of $949.08 \%$ and minimum of $-128.74 \%$ for the largest fund, it appears the distribution of Vanguard ETFs' increase in market capitalization is to the right of that of the largest funds. For first entrants and other ETFs that existed prior to Vanguard's entrance, the average increase is $86.78 \%$ and $248.20 \%$ and the median increase is $27.27 \%$ and $54.64 \%$, respectively. Both the averages and the medians are positioned between the corresponding numbers of the largest funds and Vanguard ETFs. Among the four groups, it appears that the largest funds experience the lowest increase in market capitalization one year after Vanguard entrance, followed by the other earlier ETFs. Vanguard gains the most in market capitalization.

We formally test the statistical significance of these differences using non-parametric tests, and results show that the differences among the three groups versus the largest fund and first entrants, respectively, are statistically significant at the level of $10 \%$. Additional pair-wise $t$-tests show that the differences between the first entrants and Vanguard ETFs and between the largest funds and Vanguard ETFs are statistically significant at $1 \%$ level. The difference between the largest funds and other earlier ETFs turns out to be statistically insignificant at the conventional $10 \%$ level. Finally, the difference between Vanguard ETFs and others is also statistically significant at $10 \%$ level. The results are not statistically significant for differences between the largest fund and the first entrant.

Results for the two-year increase in market capitalization are similar to those documented for the first year for the largest fund after the inception of Vanguard ETFs. Vanguard's ETFs' market capitalization increased in the second year by an average of $1,608.63 \%$, with the median increase of $627.93 \%$. These numbers exceed the increases in the first year by $2.71(=1,608.63 \% / 593.61 \%)$ and 3.45 $(=627.93 \% / 182.11 \%)$ times. The corresponding numbers are 3.18 and 2.59 for largest funds, 2.67 and 1.69 for first entrants and 2.05 and 1.70 times for other incumbents. To arrive at such two-year increase, it appears that Vanguard ETFs' market

5 We thank an anonymous reviewer for this suggestion.

6 The adjusted market capitalization used in Table 5 adjusts for the overall market trend, measured by the ratio of SPY's market capitalization between years. Specifically, the adjusted 1-year market capitalization of each ETF is estimated as market capitalization ${ }_{\text {year } 0} \times($ SPY market

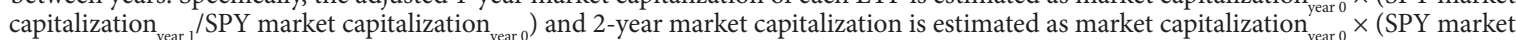
capitalization $_{\text {year } 2}^{\text {ear }} /$ SPY market capitalization ${ }_{\text {year } 0}$ ). 
Table 5. Percentage of change in adjusted market capitalization* one and two years after the entrance of low fee ETFs

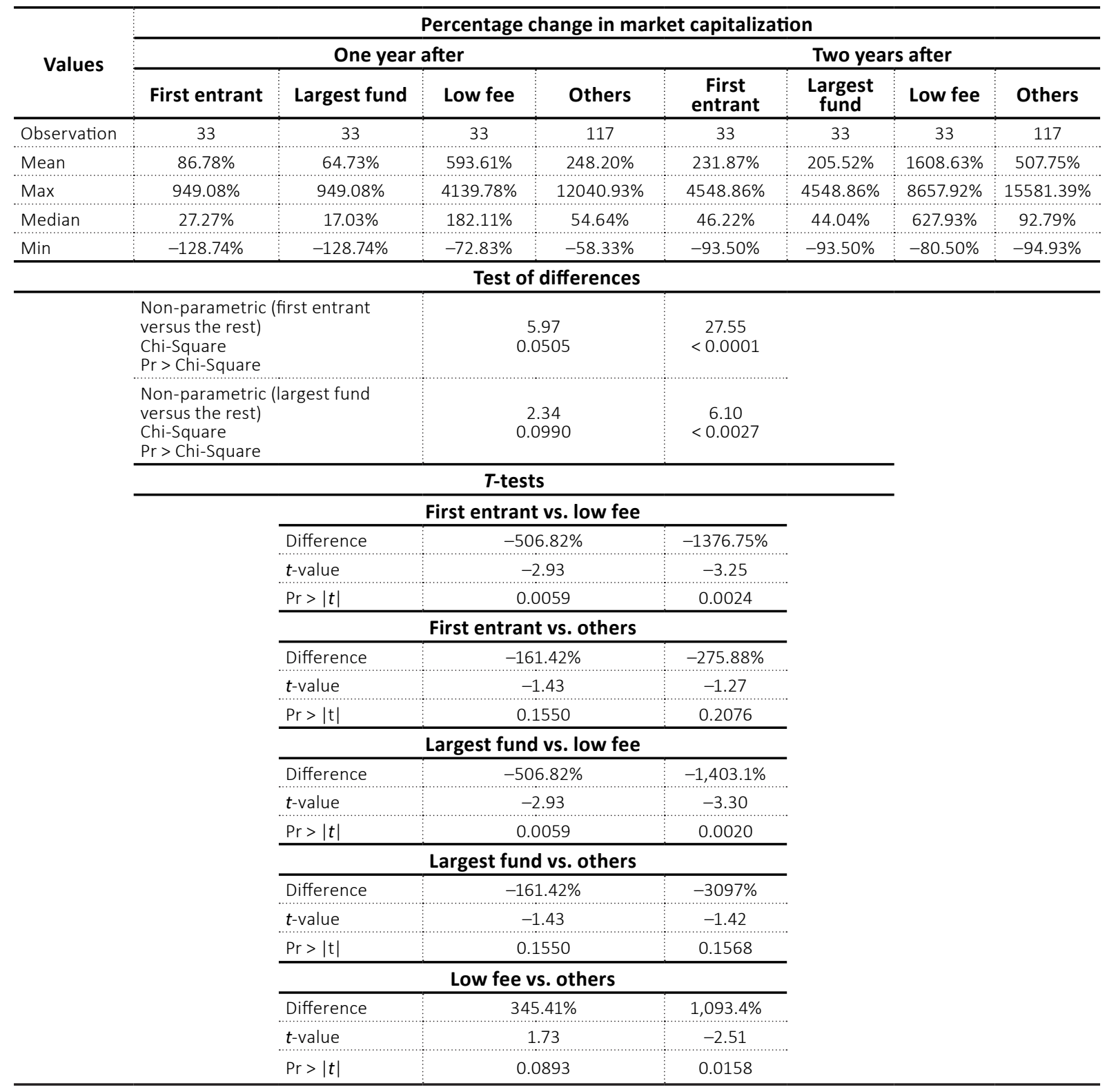

Note: * Adjusted market capitalization: adjusting for the overall market trend, measured by the ratio of SPY's market capitalization between years. Specifically, the adjusted 1-year market capitalization of each ETF is estimated as market

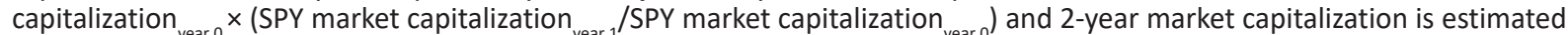
as market capitalization year $0^{\text {year }} \times\left(\right.$ SPY market capitalization ${ }_{\text {year } 2} /$ SPY market capitalization year $\left._{0}\right)$.

caps would have to continue to increase at a higher pace in the second years after the inception. These increases, which are relatively large compared to the first entrants', largest funds' and other incumbents' results for the same time period, reflect the rapid rise of Vanguard to third place in market capitalization, which it enjoys today ${ }^{7}$.

\subsection{Results of the analysis of market share after the entry of low fee ETF}

In additional robustness tests, we further analyze how low fee provider Vanguard gained a foothold in the market by comparing Vanguard's change in market share to that of the first entrant, largest

$7 \quad$ We also use the dollar amounts upon the request of the reviewer. These results indicate that the first mover's market cap increases more than low fee funds one year, but not two years, after the entrance of low fee funds. Interestingly, low fee funds increase more than existent funds two years after entry. 
Table 6. Percentage of change in market share one and two years after the entrance of low fee ETFs

\begin{tabular}{|c|c|c|c|c|c|c|c|c|}
\hline \multirow{3}{*}{ Values } & \multicolumn{8}{|c|}{ Percentage change in market share } \\
\hline & \multicolumn{4}{|c|}{ One year after } & \multicolumn{4}{|c|}{ Two years after } \\
\hline & First entrant & Largest fund & Low fee & Others & $\begin{array}{c}\text { First } \\
\text { entrant }\end{array}$ & $\begin{array}{l}\text { Largest } \\
\text { fund }\end{array}$ & Low fee & Others \\
\hline Observation & 33 & 33 & 33 & 117 & 33 & 33 & 33 & 117 \\
\hline Mean & $42.87 \%$ & $82.74 \%$ & $611.61 \%$ & $267.60 \%$ & $-3.25 \%$ & $234.64 \%$ & $1,637.78 \%$ & $544.61 \%$ \\
\hline Max & $14.10 \%$ & $984.82 \%$ & $4,167.31 \%$ & $1,2084.10 \%$ & $12.90 \%$ & $4,551.40 \%$ & $8,703.21 \%$ & $15,577.34 \%$ \\
\hline Median & $11.30 \%$ & $31.08 \%$ & $180.59 \%$ & $61.65 \%$ & $-2.60 \%$ & $74.13 \%$ & $658.01 \%$ & $125.49 \%$ \\
\hline \multirow[t]{25}{*}{ Min } & $-22.70 \%$ & $-49.92 \%$ & $-44.83 \%$ & $-55.90 \%$ & $-26.70 \%$ & $-43.83 \%$ & $-18.97 \%$ & $-63.30 \%$ \\
\hline & \multicolumn{8}{|c|}{ Test of differences } \\
\hline & \multicolumn{2}{|c|}{$\begin{array}{l}\text { Non-parametric (first entrant) } \\
\text { Chi-Square } \\
\text { Pr }>\text { Chi-Square }\end{array}$} & \multicolumn{2}{|c|}{$\begin{array}{c}5.97 \\
0.0505\end{array}$} & & \multicolumn{3}{|c|}{$\begin{array}{l}27.55 \\
<.0001\end{array}$} \\
\hline & \multicolumn{2}{|c|}{$\begin{array}{l}\text { Non-parametric (largest fund) } \\
\text { Chi-Square } \\
\mathrm{Pr}>\text { Chi-Square }\end{array}$} & \multicolumn{2}{|c|}{$\begin{array}{c}2.34 \\
0.0990\end{array}$} & & \multicolumn{3}{|c|}{$\begin{array}{l}6.10 \\
<.0027\end{array}$} \\
\hline & & \multicolumn{7}{|c|}{$T$-tests } \\
\hline & & \multicolumn{7}{|c|}{ First entrant vs. low fee } \\
\hline & & Difference & \multicolumn{2}{|c|}{$-5.27 \%$} & & \multicolumn{3}{|c|}{$-5.45 \%$} \\
\hline & & $t$-value & \multicolumn{2}{|c|}{-2.80} & & \multicolumn{3}{|c|}{-3.51} \\
\hline & & $\operatorname{Pr}>|t|$ & \multicolumn{2}{|c|}{0.0069} & & \multicolumn{3}{|c|}{0.001} \\
\hline & & \multicolumn{7}{|c|}{ First entrant vs. others } \\
\hline & & Difference & \multicolumn{2}{|c|}{$-2.82 \%$} & & \multicolumn{3}{|c|}{$-2.74 \%$} \\
\hline & & $t$-value & \multicolumn{2}{|c|}{-1.87} & & \multicolumn{3}{|c|}{-1.90} \\
\hline & & $\operatorname{Pr}>|t|$ & \multicolumn{2}{|c|}{0.069} & & \multicolumn{3}{|c|}{0.0648} \\
\hline & & \multicolumn{7}{|c|}{ Largest fund vs. low fee } \\
\hline & & Difference & \multicolumn{2}{|c|}{$-528.90 \%$} & & & $-1403.10 \%$ & \\
\hline & & $t$-value & & 08 & & & -3.31 & \\
\hline & & $\operatorname{Pr}>|t|$ & & 041 & & & 0.0020 & \\
\hline & & & & Largest & und vs. ot & ers & & \\
\hline & & Difference & -184 & $.90 \%$ & & & $-309.90 \%$ & \\
\hline & & $t$-value & & 66 & & & -1.43 & \\
\hline & & $\operatorname{Pr}>|t|$ & & 003 & & & 0.1556 & \\
\hline & & & & Low $f$ & e vs. othe & & & \\
\hline & & Difference & 344 & $01 \%$ & & & $1093.20 \%$ & \\
\hline & & $t$-value & & 72 & & & 2.51 & \\
\hline & & $\operatorname{Pr}>|t|$ & & 908 & & & 0.0157 & \\
\hline
\end{tabular}

fund, and other existing ETFs one and two years after the inception of Vanguard ETFs. Changes in market share may indicate that a low fee strategy is effective in overcoming the entrenchment of earlier entrants. Vanguard sponsors ETFs in 33 out of a total 64 existing ETF categories. For categories in which Vanguard has more than one ETF, we select for comparison the oldest Vanguard ETF in that category. Table 6 describes the changes in market share, adjusted for the overall movement of the market using the SPY as the market index ${ }^{8}$.

Our tests reveal that first entrants experience an average increase of $42.87 \%$ and a median increase of $11.30 \%$. Largest funds experience a mean increase of $82.74 \%$ and a median increase of $31.08 \%$ in market share one year after the introduction of Vanguard ETFs. By comparison, the Vanguard ETFs achieve an average increase of $611.61 \%$ and a median increase of $180.59 \%$. Consistent with the changes in market capitalization, the Vanguard ETF's experience a maximum increase of $4,167.31 \%$ and minimum of $-44.83 \%$, compared to a maximum of $984.82 \%$ and minimum of $-49.92 \%$ for the largest funds and a maximum and minimum of $14.10 \%$ and $-22.70 \%$ for first entrants. The distribution of Vanguard ETFs' increase in market share is to the right of that of the

8 The adjusted market share used in Table 6 adjusts for the overall market trend, measured by the ratio of SPY's market share between years.

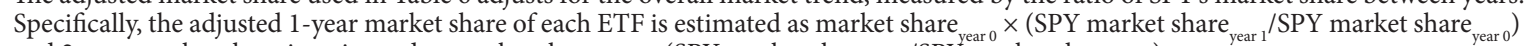
and 2-year market share is estimated as market share year $0 \times\left(\right.$ SPY market share year $2 /$ SPY $_{\text {market share }}$ year 0$)$. 
first entrants, largest funds and other ETFs. For other ETFs that existed prior to Vanguard's entrance, the average increase is $267.60 \%$ and the median increase is $61.65 \%$. First entrants and largest funds experience the smallest increases in market share, other ETFs experience greater average gains and Vanguard experiences the largest market share gains.

We formally test the statistical significance of these differences, and results show that the differences among the three groups (first entrant versus low fee and others, and largest fund versus low fee and others, respectively) are statistically significant at a level of $10 \%$ based on nonparametric tests. Additional pair-wise $t$-tests show that the difference between the first entrants and Vanguard ETFs and largest funds and Vanguard ETFs is statistically significant at $1 \%$ level. The difference between the largest funds and other earlier ETFs is statistically insignificant at the conventional $10 \%$ level. Finally, the difference between Vanguard ETFs and other ETFs change in market share is also statistically significant at $10 \%$ level.
Results for the two-year increases in market share are similar to those documented for the first year after the inception of Vanguard ETFs. Vanguard's ETFs' market share increased in the two years following the inception by an average of $1,637.78 \%$, with the median increase of $658.01 \%$. These numbers exceeded the first year for the average by $2.68(=1,637.78 \% / 611.61 \%)$ and 3.64 $(=658.01 \% / 180.59 \%)$ times for the median. The market share losses continued for the first entrants and increases continued for largest funds and other existing ETFs. The corresponding numbers are 1.13 and 2.00 times for the first entrants, 2.84 and 2.39 times for largest funds, and 2.04 times for both the average and median for other incumbents. The results in Table 6 show that Vanguard ETFs' experience continued increases in market share two years after their inception that is statistically significant relative to first entrants, largest funds and other ETFs. These results coincide with the changes in market capitalization experienced by Vanguard over the same period and further support the success of the low fee strategy. Once again, we do not find evidence of a first entrant or largest fund advantage.

\section{CONCLUSION}

In the 20 years since its inception, the ETF industry has grown to 1,487 individual products and over USD 1.2 trillion in assets. As new participants enter the market, they increase the supply of available products and the competition for investors' funds becomes more severe. A predictable economic response to this stage in an industry's business cycle is price reduction. Naturally, all else being equal, newcomers should experience greater competitive pressure than older, more established firms. We aim to investigate if these processes are at work in the ETF market and whether the new entrants' cost-cutting strategies produce desired results. This investigation is also motivated by the earlier body of research on conventional mutual funds, which surprisingly reveals the positive correlation between expense ratios and net funds flows.

We document a positive relationship between the age of funds and their net asset values, which is consistent with the intuition that funds introduced to the market earlier enjoy a competitive advantage over the later entrants, although we do not find evidence to support a first mover effect per se. Similarly, we do not find evidence that the largest fund in the fund category experiences increases in net asset value relative to Vanguard over the subsequent one- or two-year periods. At the same time, our results indicate that, in the case of ETFs, investors are aware that there may be benefits to low cost funds, as we document increases in net asset value to new entrants with low costs. This conclusion is confirmed by regression results as well as the examination of the apparent success of Vanguard funds, despite its later arrival to the ETF market, compared to other investment firms. Our results that the lower cost strategy achieves the goal of increased NAV, which is supported by increases in market capitalization and market share for Vanguard (the low cost leader), have implications for ETF sponsors and investors, both of whom appear to acknowledge of the benefits of low cost funds. Schwab and Blackrock's recent fee cuts, 
as well as the offering of commission-free trading among ETF providers and brokerage houses, provide further evidence that the low fee strategy may be viewed as effective for ETF providers and brokerage houses.

\section{REFERENCES}

1. Agapova, A. (2011). Conventional Mutual Index Funds versus Exchange Traded Funds. Journal of Financial Markets, 14(2), 323343. https://doi.org/10.1016/j. finmar.2010.10.005

2. Barber, B. M., \& Odean, T. (2001). Boys will be boys: gender, over-confidence, and common stock investment. The Quarterly Journal of Economics, 116(1), 261-292. https://doi. org/10.1162/003355301556400

3. Barber, B., Odean, T., \& Zheng, L. (2005). Out of sight, out of mind: The effects of expenses on mutual fund flows. The Journal of Business, 78(6), 2095-2119. https://doi. org/10.1086/497042

4. Capon, N., Fitzsimons, G. J., \& Prince, R. A. (1996). An Individual Level Analysis of the Mutual Fund Investment Decision. Journal of Financial Services Research, 10(1), 59-82. https://doi. org/10.1007/BF00120146

5. Carhart, M. M. (1997). On persistence in mutual fund performance. The Journal of Finance, 52(1), 57-82. https://doi. org/10.2307/2329556

6. Choi, J. J., Laibson, D., \& Madrian B. C. (2010). Why does the law of one price fail? An experiment on index mutual funds. The Review of Financial Studies, 23(4), 14051432. https://doi.org/10.1093/rfs/ hhp097

7. Christoffersen, S. E. K., \& Musto, D. K. (2002). Demand curves and the pricing of money management. The Review of Financial Studies, 15(5), 1499-1524. https://doi. org/10.1093/rfs/15.5.1499

8. De Long, J. B., Shleifer, A., Summers, L. H., \& Waldmann, R. J. (1990). Noise trader risk in financial markets, Journal of Political Economy, 98(4), 703-738. https://doi.org/10.1086/261703
9. Elton, E. J., Gruber, M. J., Comer, G., \& Li, K. (2002). Spiders: Where Are the Bugs? The Journal of Business, 75(3), 453-472. https:// doi.org/10.1086/339891

10. Gastineau, G. L. (2001). ExchangeTraded Funds: An Introduction. The Journal of Portfolio Management, 27(3), 88-96. https:// doi.org/10.3905/jpm.2001.319804

11. Gastineau, G. L. (2004). The Benchmark Index ETF Performance Problem. The Journal of Portfolio Management, 30(2), 96-103. https://doi.org/10.3905/ jpm.2004.319935

12. Gil-Bazo, J., \& Ruiz-Verdu, P. (2009). The relation between price and performance in the mutual fund industry. The Journal of Finance, 64(5), 2153-2183. https://doi.org/10.1111/j.15406261.2009.01497.x

13. Gruber, M. (1996). Another puzzle: The growth in actively managed mutual funds. The Journal of Finance, 51(3), 783-810. https://doi. org/10.1111/j.1540-6261.1996. tb02707.x

14. Hortaçsu, A., \& Syverson, C. (2004). Product differentiation, search costs, and competition in the mutual fund industry: A case study of S\&P 500 index funds. The Quarterly Journal of Economics, 119(2), 403-456. https://doi. org/10.1162/0033553041382184

15. Investment Company Institute (2016). Investment Company Factbook. Retrieved from https:// www.ici.org/pdf/2016_factbook. pdf

16. Ivkovic, Z., \& Weisbenner, S. (2009). Individual investors mutual-fund flows. The Journal of Financial Economics, 92(2), 223-237. https://doi.org/10.1016/j. jifineco.2008.05.003
17. Jain, P. C., \& Wu, J. S. (2000) Truth in mutual fund advertising: Evidence on future performance and flows. The Journal of Finance, 55(2), 937-958. https://doi. org/10.1111/0022-1082.00232

18. Jegadeesh, N., \& Titman, S. (1993). Returns to buying winners and selling losers: Implications for stock market efficiency. The Journal of Finance, 48(1), 65-91. https://doi. org/10.1111/j.1540-6261.1993. tb04702.x

19. Kostovetsky, L. (2003). Index Mutual Funds and ExchangeTraded Funds. The Journal of Portfolio Management, 29(4), 80-92. https://doi.org/10.3905/ jpm.2003.319897

20. Navone, M. (2012). Investors' distraction and strategic repricing decisions. Journal of Banking and Finance, 36(5), 1291-1303. https://doi.org/10.1016/j.jbankfin.2011.11.018

21. Odean, T. (1998). Are investors reluctant to realize their losses? The Journal of Finance, 53(5), 1775-1798. https://doi. org/10.1111/0022-1082.00072

22. Odean, T. (1999). Do investors trade too much? American Economic Review, 89(5), 12791298. http://doi.org/10.1257/ aer.89.5.1279

23. Salisbury, Ian. (July 30, 2012). As BlackRock's Rivals Chip Away, ETF Fees Could Be Next to Fall. Wall Street Journal. Retrieved from http://online.wsj.com/article/SB10 0008723963904448601045775590 94163071410.html

24. Wilcox, R. T. (2003). Bargain hunting or star gazing? Investors' preferences for stock mutual funds. The Journal of Business, 76(4), 645-664. http://doi. org/10.1086/377034 